IZA DP No. 9498

Education, Health and Fertility of UK Immigrants: The Role of English Language Skills

Yu Aoki

Lualhati Santiago

November 2015 


\title{
Education, Health and Fertility of UK Immigrants: The Role of English Language Skills
}

\author{
Yu Aoki \\ University of Aberdeen \\ and IZA \\ Lualhati Santiago \\ Office for National Statistics
}

\author{
Discussion Paper No. 9498 \\ November 2015
}

\author{
IZA \\ P.O. Box 7240 \\ 53072 Bonn \\ Germany \\ Phone: +49-228-3894-0 \\ Fax: +49-228-3894-180 \\ E-mail: iza@iza.org
}

Any opinions expressed here are those of the author(s) and not those of IZA. Research published in this series may include views on policy, but the institute itself takes no institutional policy positions. The IZA research network is committed to the IZA Guiding Principles of Research Integrity.

The Institute for the Study of Labor (IZA) in Bonn is a local and virtual international research center and a place of communication between science, politics and business. IZA is an independent nonprofit organization supported by Deutsche Post Foundation. The center is associated with the University of Bonn and offers a stimulating research environment through its international network, workshops and conferences, data service, project support, research visits and doctoral program. IZA engages in (i) original and internationally competitive research in all fields of labor economics, (ii) development of policy concepts, and (iii) dissemination of research results and concepts to the interested public.

IZA Discussion Papers often represent preliminary work and are circulated to encourage discussion. Citation of such a paper should account for its provisional character. A revised version may be available directly from the author. 


\section{ABSTRACT \\ Education, Health and Fertility of UK Immigrants: The Role of English Language Skills*}

This paper aims to identify the causal effect of English language skills on education, health and fertility outcomes of immigrants in England and Wales. We construct an instrument for language skills using age at arrival in the United Kingdom, exploiting the fact that young children learn languages more easily than older children and adults. Using a unique individual-level dataset that links 2011 census data to life event records for the population living in England and Wales, we find that better English language skills significantly lower the probability of having no qualifications and raise that of obtaining academic degrees, but do not affect child health and self-reported adult health. The impact of language on fertility outcomes is also considerable: Better English skills significantly delay the age at which a woman has her first child, lower the likelihood of becoming a teenage mother, and decrease fertility.

JEL Classification: $\quad 110,120, J 13$

Keywords: language skills, education, health, fertility

Corresponding author:

Yu Aoki

Department of Economics

University of Aberdeen

Dunbar Street

Old Aberdeen, AB24 3QY

United Kingdom

E-mail:y.aoki@abdn.ac.uk

\footnotetext{
* The permission of the Office for National Statistics (ONS) to use the Longitudinal Study is gratefully acknowledged, as well as the help and support of Nicky Rogers, Richard Prothero and the Longitudinal Study Development Team at ONS. We would like to thank the participants of the EALE/SOLE meeting in Montreal, ESPE conference in Izmir, BSPS conference in Leeds, Health Economics conference in Essen, Applied Economics of Education workshop in Catanzaro, and seminars/workshops at the University of Aberdeen, the University of Alicante and CPB Netherlands Bureau for Economic Policy Analysis for discussions that improved this paper. The authors alone are responsible for the interpretation of the data. Financial support from the Carnegie Trust for the Universities of Scotland and the Scottish Institute for Research in Economics is also gratefully acknowledged. This work contains statistical data from the ONS which is Crown Copyright and all statistical results remain Crown Copyright. The use of the ONS Statistics statistical data in this work does not imply the endorsement of the ONS in relation to the interpretation or analysis of the statistical data. This work uses research datasets which may not exactly reproduce National Statistics aggregates.
} 


\section{Introduction}

The foreign-born share of the population increased in most OECD countries between 2000/01 and 2009/10 (OECD, 2012), and the social integration of immigrants is high on the policy agenda of developed countries. In order to implement successful policies to target social and health inequalities among their immigrant population, policy makers need to understand what barriers immigrants face to integrate. Among possible barriers, this paper focuses on language. Language facilitates access and use of public services, such as those related to education and health, and this in turn may affect the educational achievement and health of immigrants. There is extensive evidence that better language skills improve immigrants' economic status, in particular their earnings, but there is limited research on how language affects their social life and family structures (Chiswick \& Miller, 2014). There is also limited knowledge on how language affects immigrants' health outcomes and behaviour. This paper aims to contribute to this literature by identifying the causal effect of English language skills on a number of education, health and fertility outcomes for immigrants in England and Wales.

Our paper contributes to the literature on the effect of language skills on these social outcomes in a number of ways. First, we use a unique dataset from the Office for National Statistics England and Wales Longitudinal Study, which links individual-level dataset from the 2011 Census for England and Wales and Live Births to Sample Mothers, which contains information on births to sample women in the longitudinal study. The combination of these two datasets allows us to study the impact of language skills on various fertility outcomes that, to the best of our knowledge, have not been studied before: a woman's age at having her first child, the number of children she gives birth to, and the birthweight of her children. Second, we are first to provide evidence on how language skills affect health outcomes of immigrants in England and Wales. Research on the relation between language skills and health of immigrants in the United Kingdom (UK) is very limited because there are very few health datasets in the UK that incorporate information on English language skills (Jayaweera, 2014). Third, we provide an important contribution to the literature by presenting results from a country with a very different immigration composition to that of the United States (US), the country on which most studies in this literature are based. OECD (2012) indicates that the UK and the US have similar shares of immigrants $-11.3 \%$ of the total population in the UK, $12.5 \%$ in the US - but the two countries are different in a key characteristic of interest to our analysis: $47 \%$ of immigrants in the UK come from an English-speaking country, compared to $20 \%$ of immigrants in the US. In addition, $47 \%$ of immigrants in the UK are highly educated, compared to $34 \%$ among immigrants in the US, and $34 \%$ of immigrants in the UK come from an OECD high-income country, compared to only $14 \%$ of immigrants in the US. Lastly, this is the first paper that explicitly accounts for parental 
education, which is a possible important omitted variable in the analyses of the causal effects of English language skills on education and health outcomes.

Credibly identifying and quantifying the impact of language proficiency on education, health and fertility outcomes poses a significant empirical challenge because English language proficiency is likely to be endogenous. First, unobserved heterogeneity across individuals that affects both English proficiency and these social outcomes, such as ability and cultural attitude, may bias estimates of the effect of English proficiency. Second, these social outcomes can also affect an individual's English proficiency (reverse causality); for example, having children might improve a woman's English skills if this leads her to interact more frequently with English-speaking parents, schoolteachers or healthcare professionals. Third, measurement errors in the measure of English proficiency can also cause a bias in the Ordinary Least Squares (OLS) estimator.

To address this endogeneity problem, we use an instrumental variable (IV) strategy, where we exploit age at arrival in the UK to construct an instrument for English skills. Bleakley \& Chin (2004) were first to exploit age at arrival to construct an IV for language skills of immigrants, based on the "critical period hypothesis" of language acquisition. This hypothesis, first proposed by Lenneberg (1967), states that a person exposed to a language within the critical period of language acquisition (i.e., childhood) can learn it more easily, implying that non-English-speaking immigrants who arrived in the UK when they were young children have on average better English language skills than those who arrived when they were older.

However, age at arrival alone is not a valid instrument because it is likely to have direct effects on the social outcomes of immigrants through channels different from language acquisition; for example, through cultural assimilation or better knowledge of UK institutions and social services, such as education and healthcare systems. To address these concerns, we use immigrants from English-speaking countries as a control to partial out age-at-arrival effects that affect the social outcomes of immigrants through channels different from language acquisition. More precisely, conditional on individual characteristics, any difference observed in the outcomes of early- and late-arrivers coming from English-speaking countries would reflect an age-at-arrival effect, while this same difference, for the case of immigrants coming from non-English-speaking countries, would reflect an age-at-arrival effect and an additional effect, namely, the language effect. Thus, the difference in outcomes between early- and late- arrivers coming from non-English-speaking countries in excess of its equivalent difference for immigrants coming from English-speaking countries can arguably be attributed to the effect of language. Based on this idea, we construct an IV which is the interaction of age at arrival and an indicator for coming from a non-Englishspeaking country.

Our IV estimates indicate that better English language skills significantly raise the probability of obtaining an academic degree and significantly lower the probability of having no 
qualifications, but do not affect self-reported adult health and child health, measured by child's birthweight. The impact of language skills on fertility outcomes is also considerable: Better English skills significantly delay the age at which a woman has her first child, lower the likelihood of becoming a mother in her teens, and decrease the number of children a woman gives birth to.

The remainder of the paper proceeds as follows. Section 2 reviews the literature on the effect of language skills on immigrants' social outcomes. Section 3 presents our econometric specification and discusses empirical problems and our identification strategy. Section 4 describes our sample and data on education, health and fertility. Our main empirical findings are discussed in Section 5. Section 6 investigates the robustness of our main results to different sample and regression specifications. Finally, Section 7 discusses policy implications and concludes the paper.

\section{Literature Review}

The literature that explores the causal effect of language skills on education, health and fertility outcomes is not extensive. The relation between language skills and education has been explored in a limited number of studies; for example, Glick \& White (2003) analyse factors that may explain the academic performance of immigrants and find that having a non-English background is associated with lower test scores of immigrants in the US. The majority of studies that explore the educational attainment of immigrants do not focus directly on language proficiency, and instead study how age at arrival affects their ability to close the education gap with natives and second-generation immigrants (e.g., Böhlmark, 2008; Cortes, 2006). The conclusions drawn in some of these studies suggest that language proficiency could be a key factor explaining the educational attainment of immigrant children. For example, Corak (2011) finds a negative impact of age at arrival on holding a high school diploma for immigrant children who arrived in Canada after age nine, but only for those arriving from non-English- or non-French-speaking countries. Also, Cohen Goldner \& Epstein (2014), using data from Israel, arrive to a similar conclusion: Age at arrival has a negative impact on the probability of graduating from high school, and they suggest that a possible channel for this may be language acquisition.

A challenge for studying the effect of language skills on education is that causation is difficult to establish because language skills are endogenous; for instance, better language skills help achieve better academic results, but studying for a higher degree also helps improve one's language ability since it requires extensive reading and writing. To overcome the endogeneity of language skills, Bleakley \& Chin (2004) and Akbulut-Yuksel et al. (2011) create an IV for language skills using an interaction between age at arrival in the US and coming from a nonEnglish-speaking country. These two studies find that better English skills increase the number of years of schooling of immigrants coming from non-English-speaking countries. 
The role of language skills on health and fertility outcomes has been analysed by social scientists across different disciplines, including Sociology, Epidemiology and Behavioural Sciences. Most studies examine correlations between language skills and health or fertility outcomes. Regarding health outcomes, a number of papers analyse the role of language skills in the context of acculturation in the US. Their findings appear to be mixed. Kimbro et al. (2012) and Miranda et al. (2011) find a positive association between English language proficiency and health outcomes, while Bauer et al. (2012) and Lee et al. (2013) find that this correlation is insignificant. There are very few studies based on countries other than the US. $\mathrm{Ng}$ et al. (2008) investigate the effect of proficiency in the official languages in Canada (English and French) on self-reported health. Their findings indicate that poor language skills in the official languages are positively associated with poor (self-reported) health. An issue with these studies is that it is not clear if poor language skills deteriorate health due to, for example, a poor interaction with healthcare professionals, or if poor health hinders the development of language skills because it limits interactions with other people. Guven \& Islam (2015) address this endogeneity problem of language skills constructing an IV for language skills using an interaction between age at arrival in Australia and coming from a non-English-speaking country. They find that better English skills improve self-reported health and physical health, although their results appear to be sensitive to sample specifications. Clarke \& Isphording (2015) address the issue of endogeneity by using an IV which is an interaction of age at arrival in Australia and the linguistic background of the individual, and find that English deficiency significantly deteriorates the physical health of immigrants.

A small number of studies investigate the relation between language skills and fertility. Focusing on individuals in the US with Hispanic origin, Lichter et al. (2012), Gorwaney et al. (1991) and Swicegood et al. (1988) find that poor English proficiency is significantly associated with higher fertility rates. In contrast, using Canadian data, Adsera \& Ferrer (2014) find that the number of children that immigrants have increases with age at immigration relative to that of natives, regardless of language proficiency in the official languages in Canada (English and French). They find that the fertility rates of all immigrants, including those coming from Englishor French-speaking countries, are higher than those of the native-born, suggesting that language proficiency is unlikely to play a key role in explaining a higher fertility among immigrants. A possible issue with these studies is that unobserved heterogeneity that affects the fertility decision of a woman, such as cultural attitude, may be correlated with her language proficiency. Reverse causality may also be an issue. Bleakley \& Chin (2010) address this potential endogeneity using an interaction between age at arrival and coming from non-English-speaking countries as an IV for language skills of immigrants in the US. Their results suggest that a woman's English skills significantly reduce the number of children living in her household. A limitation of Bleakley \& 
Chin (2010) is that they study the number of children living in the same household as a woman at the time in which the census data was collected, which is not necessarily the actual number of children she has.

\section{Identification Strategy}

We explore the causal effect of English language proficiency on education, health and fertility outcomes of immigrants living in England and Wales by regressing these outcomes on a measure of English language proficiency, controlling for various individual characteristics. We specify the following model:

$$
\text { outcome }_{i c a}=\beta_{0}+\beta_{1} \text { proficiency }_{i c a}+X_{i c a}^{\prime} \delta+\gamma_{c}+\eta_{a}+\varepsilon_{i c a}
$$

where outcome $e_{\text {ica }}$ represents the outcome of individual $i$ born in country $c$ who arrived in the UK at age $a$, and proficiency $y_{i c a}$ is a measure of English language proficiency. ${ }^{1}$ The individual characteristics, $X_{i c a}$, and the parameter $\delta$ are $K \times 1$ vectors, where $K$ is the number of variables capturing individual characteristics such as age and gender. $\gamma_{c}$ and $\eta_{a}$ are country-of-birth and age-at-arrival fixed effects, respectively, and $\varepsilon_{i c a}$ is the disturbance term.

The main coefficient of interest is $\beta_{1}$, which measures the effect of English language proficiency on the outcomes we analyse. An econometric issue in the estimation of equation (1) is the endogeneity of English language proficiency. First, unobserved individual characteristics, such as ability and cultural attitude, are likely to be correlated with both English language skills and immigrants' social outcomes. For example, an individual with a high ability will find it easier to attain a higher level of education and will also be able to learn English more easily. It is also plausible that a high ability individual has good health because, for instance, he has a better understanding of the consequences of risky behaviours, such as smoking and drinking heavily. Thus, language proficiency could be positively correlated with educational attainment and better health even if language proficiency did not "cause" an increase in educational attainment or an improvement in health. Second, education, health and fertility outcomes of an individual may affect the person's language proficiency (reverse causality). For example, a person with poor health may not be able to improve her language skills if her health problems limit her interactions with

\footnotetext{
${ }^{1}$ Some outcomes we analyse are dummy variables. Although we could potentially specify non-linear models (e.g., probit model) for these outcomes, we use linear models for all outcomes for two main reasons. First, this allows us to be consistent in our model specification across regressions. Second, linear models have a more straightforward interpretation than non-linear models when working with instrumental variables. Angrist \& Pischke (2009) argue that, although a non-linear model may fit the conditional expectation function for limited dependent variables more closely than a linear model, marginal effects computed from these two types of models are very similar.
} 
English speakers. Also, having children can improve a woman's language skills if having children requires her to interact more frequently with English speakers, such as schoolteachers and healthcare professionals. Thus, it is hard to conclude whether social outcomes affect language skills or vice versa. Third, our measure of language proficiency is self-reported, and may contain measurement errors. For example, Dustmann \& van Soest (2001) find that a self-reported measure of language proficiency contains a substantial amount of measurement errors. For all these reasons, the OLS estimator for $\beta_{1}$ is unlikely to estimate the causal effect of English language skills.

To identify the causal effect of language skills, we use an IV strategy which requires an IV giving exogenous variation in English language skills. In this paper, we exploit age at arrival in the UK to construct an IV for language skills. The idea of using age at arrival in a host country to construct an IV for language proficiency was proposed by Bleakley \& Chin (2004) and based on the "critical period of language acquisition" hypothesis suggested by Lenneberg (1967). According to this hypothesis, an individual exposed to a new language during the critical period of language acquisition (childhood) will be able to learn the language easily, while learning a new language after this critical period is more difficult. ${ }^{2}$ The critical period hypothesis implies that age at arrival in the UK would affect English language proficiency of immigrants arriving from countries where English is not spoken as a main language because these immigrants are exposed to English for the first time when they arrive in the UK. More specifically, for immigrants arriving from non-English-speaking countries, those who arrive at an early age are likely to learn English more easily, while late-arrivers would face more difficulties in learning English and may have a poorer command of the language. In contrast, age at arrival does not affect the proficiency in English of immigrants coming from English-speaking countries, because they have been exposed to English prior to their arrival in the UK.

For a variable to be a valid IV for English language skills, we require two assumptions: namely, it does not appear in equation (1), and it is not correlated with any other determinants of immigrant social outcomes except language skills. Age at arrival alone is unlikely to satisfy these assumptions for various reasons. First, age at arrival affects not only language proficiency but also cultural assimilation; for example, fertility rates of women in some developing countries are on average higher than those of UK-born women. Immigrants who arrive in the UK at an early age from these higher-fertility countries might have low fertility rates because early-arrivers may be more influenced by UK cultural norms. Second, age at arrival can also increase an individual's knowledge about UK institutions, which may subsequently affect his social outcomes; for

\footnotetext{
${ }^{2}$ Lenneberg (1967) observes that, until early teens, individuals have an innate flexibility for the organisation of brain functions necessary for the acquisition of a language. If basic language skills have not been acquired by puberty, they tend to remain deficient for the rest of their life because the ability to adjust to physiological demands for verbal acquisition declines sharply after puberty due to physiological changes in brain.
} 
example, early-arrivers may have an advantage over late-arrivers in attaining a higher level of education because they are more familiar with the UK educational systems. Likewise, earlyarrivers may have better health partly because they have a better knowledge of the UK healthcare systems.

To address these concerns, instead of using age at arrival as an IV, we use an interaction of age at arrival with a dummy variable for coming from a non-English-speaking country. All immigrants are exposed to a new environment at arrival in the UK, but only those coming from non-English-speaking countries encounter a new language. Thus, conditional on individual characteristics, differences in outcomes of early- and late-arrivers from English-speaking countries would reflect age-at-arrival effects only, whereas differences in outcomes of those from non-English-speaking countries would reflect both language effects and age-at-arrival effects. Therefore, a difference in the outcomes between early- and late-arrivers coming from nonEnglish-speaking countries in excess of the corresponding difference for immigrants coming from English-speaking countries can be arguably attributed to the effects of language.

Figure 1 shows the relation between English language proficiency and age at arrival of immigrants in England and Wales who arrived in the UK when they were young (aged 0 to 15). The dashed and solid lines correspond to immigrants from English- and non-English-speaking countries, respectively. Figure 1 shows that immigrants born in English-speaking countries are generally proficient in English (i.e., scoring between 2.9 and 3 in the ordinal measure of English proficiency, where 3 corresponds to "speaks very well") irrespective of their age at arrival. This is not surprising because they were exposed to English prior to their arrival in the UK. In contrast, immigrants born in non-English-speaking countries who arrived in the UK after age eight report having a poorer command of English than those who arrived before age eight. The two series start diverging at around age nine and, for those individuals born in non-English-speaking countries, the later they arrived, the poorer their English is on average. This observation is consistent with the critical period hypothesis. The pattern observed in Figure 1 leads us to parametrise age at arrival of individual $i$ born in country $c$ who arrived in the UK at age $a, \theta_{\text {ica }}$, in the following manner:

$$
\theta_{i c a}=\max \left(0, \text { arrival }_{i}-8\right) \times I(i \text { coming from a non }- \text { English }- \text { speaking country })
$$

where arrival $_{i}$ is age at arrival for individual $i$ and $I(\cdot)$ is an indicator function that equals one if the individual comes from a non-English-speaking country, and zero otherwise. $\max \left(0\right.$, arrival $_{i}-$ 8) measures the additional years after age eight for those who arrived in the UK after age eight, and zero otherwise. An assumption underlying equation (2) is that there is no difference in En- 


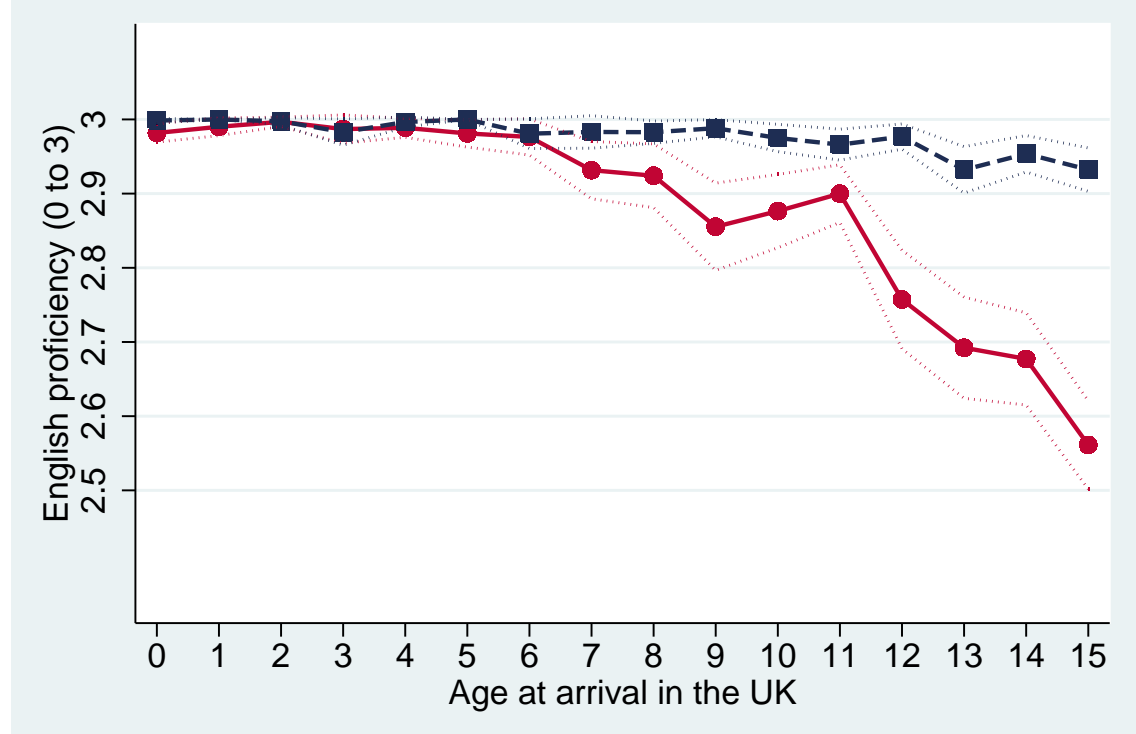

$\longrightarrow$ Non-English-speaking country of birth ----- English-speaking country of birth

Figure 1: Age at Arrival and English Proficiency

Notes: Figure plots the average ordinal measure of English proficiency, where 3, 2, 1, and 0 correspond to speaks "very well", "well", "not well", and "not at all", respectively. English proficiency is regression adjusted for age. Two sets of outer lines correspond to 95 per cent confident intervals. The sample corresponds to childhood immigrants aged 20 to 60 at the time of Census 2011. 
glish language proficiency between immigrants from English- and non-English-speaking countries for those who arrived at age eight or before, but language proficiency and age at arrival are linearly related after age eight for immigrants coming from non-English-speaking countries. We choose the age eight as the cut-off value because, for those who arrived in the UK at age eight or before, there is no significant difference in English skills as adults irrespective of whether they come from English- or non-English-speaking countries (cf. Figure 1). ${ }^{3}$ Using equation (2), the relation between proficiency in English and age at arrival, which corresponds to our first-stage equation, can be specified as follows:

$$
\text { proficiency }_{i c a}=\alpha_{0}+\alpha_{1} \theta_{i c a}+X_{i c a}^{\prime} \zeta+\iota_{c}+\kappa_{a}+u_{i c a}
$$

where the individual characteristics, $X_{i c a}$, and the parameter $\zeta$ are $K \times 1$ vectors, where $K$ is the number of variables capturing individual characteristics. $l_{c}$ and $\kappa_{a}$ are country-of-birth and age-at-arrival fixed effects, respectively, and $u_{i c a}$ is the disturbance term.

Figure 2 plots education, fertility and health outcomes by age at arrival: Namely, panels A to $\mathrm{C}$ plot the likelihood of having no qualifications, that of having a child in her teens (women only), and self-reported health ordinal measure, respectively. ${ }^{4}$ The dashed and solid lines correspond to immigrants from English- and non-English-speaking countries, respectively. Panels A and B show that, among early arrivers, the likelihood of having no qualifications and that of becoming a teenage mother are similar across the two sets of immigrants. In contrast, among late arrivers, the likelihood of having no qualifications and that of becoming a teenage mother are higher for those from non-English-speaking countries. Panel $\mathrm{C}$ shows a different pattern: for early arrivers, self-reported health measures follow similar patterns across the two language-origin groups, while immigrants from non-English-speaking countries appear to report better health among late arrivers.

In order for this IV strategy to identify the causal effect of language skills, we require an additional assumption that those born in English- and non-English-speaking countries are exposed to the same age-at-arrival effects, except for the language effect. However, this assumption could be questionable. One concern is that these two groups of immigrants could be facing different age-at-arrival effects because they have different background characteristics. For example, a significant proportion of immigrants born in non-English-speaking countries come from European countries, e.g., Germany. These European countries have close economic and political ties and

\footnotetext{
${ }^{3}$ We have also used as cut-off values ages seven and nine. Our results are not sensitive to the changes in the cut-off value.

${ }^{4}$ As we have numerous outcome variables, we do not report graphs for every outcome for the sake of space. Instead, we report the relation between age at arrival and each education, health and fertility outcome under consideration (i.e., our reduced-form estimates) in Table 3.
} 


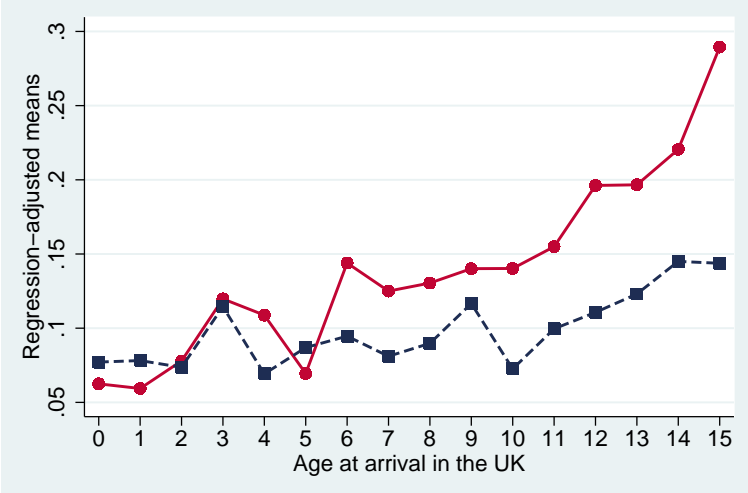

A. No qualifications

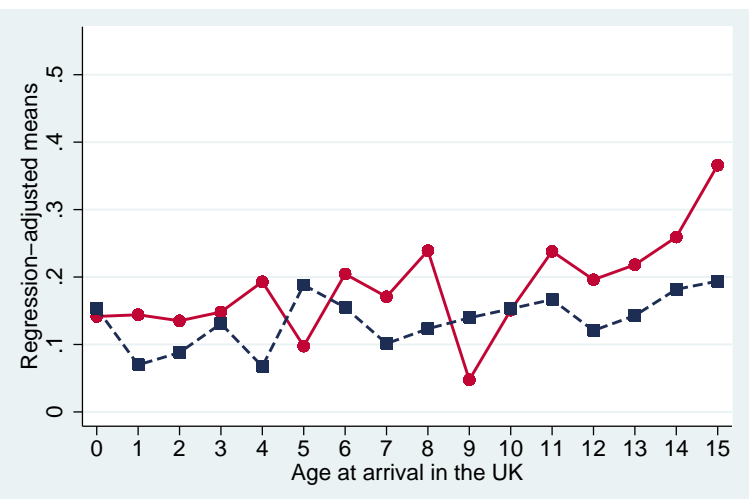

B. Teenage mother

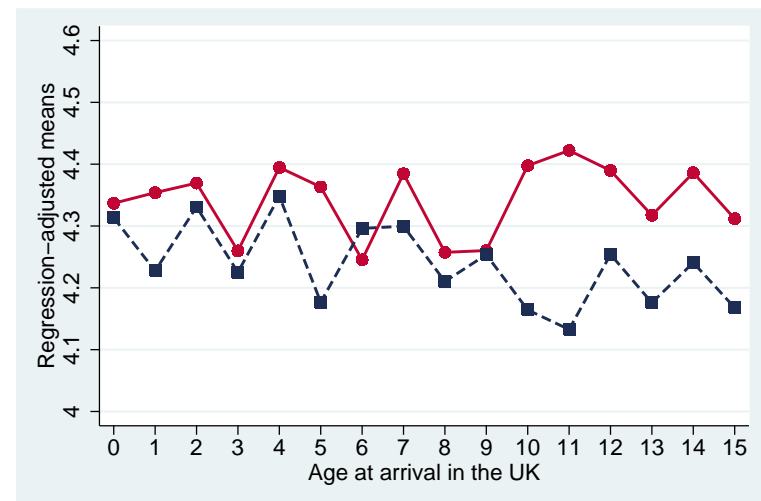

C. Self-reported health (1 to 5)

Non-English-speaking country of birth ------ English-speaking country of birth

Figure 2: Education, Fertility and Health by Age at Arrival

Notes: Panels A, B and C plot measures of education (likelihood of having no qualifications), fertility (likelihood of having first child in teens) and health (self-reported health), respectively, by age at arrival. Every outcome is regression adjusted for age. 
cultural commonalities with the UK due to, for example, a long history of economic, political and cultural interactions (e.g., the European Union), and this makes it potentially easier for them to adapt to the new UK environment. Likewise, a significant proportion of immigrants born in English-speaking countries come from Commonwealth countries, which share commonalities with the UK regarding, for example, culture and legal systems, also making it potentially easier for these individuals to adapt to the UK environment. As long as these country-of-origin specific effects do not vary across age at arrival, they will be absorbed by country-of-origin fixed effects in equation (1). Still, one could be concerned that these country-of-origin specific effects could vary across age at arrival, and we address these issues in Section 6, where we present a series of robustness checks to address these concerns.

\section{Data and Sample}

\subsection{Data}

We use data from the Office for National Statistics (ONS) England and Wales Longitudinal Studies (LS), an individual-level dataset comprising linked census and life event records for $1 \%$ of the population of England and Wales. We make use of two datasets that are part of the LS: The 2011 Census for England and Wales, and the Live Births to Sample Mothers (LBSM), which contains information of live births to women usually resident in England and Wales taken from the birth registration and birth certificate for the period 1971 to $2011 .^{5}$ We create our fertility outcomes using data from the LBSM dataset, and they apply only to mothers in our LS dataset that are also present in the LBSM dataset. Our measures of fertility are: Birthweight of child, age of woman when her first child was born, a dummy for whether a woman had her first child in her teens, and number of children born to a woman. This latter variable is a better measure of the actual number of children born to a mother than the usual census variable of number of dependent children living in same household used in most studies that analyse census data (e.g., Bleakley \& Chin, 2010).

Our measures on education and health are also obtained from the 2011 Census. We construct our set of education indicator variables from one single variable in the 2011 Census, which collects self-reported information on the highest level of education achieved by the individual. The 2011 Census also collects information on self-reported health, which is an ordinal measure ranging between 1 (very bad health) to 5 (very good health); from this variable, we derive two additional indicator variables: "good or very good health" and "bad or very bad health". We use

\footnotetext{
${ }^{5}$ The dataset contains a variable that records the number of children previously born alive to sample mother. Prior to May 2012, this information was only collected for births within marriage. The registrar records the number of previous live-born children that a woman has had by her present husband and any former husband. Therefore some births may have not been recorded, or were only recorded if the mother gave the relevant information to the registrar.
} 
an additional measure of health that comes from another question in Census 2011: An indicator variable for self-reported long-term health problems.

The variables capturing language skills and individual characteristics come from the 2011 Census. Using information on self-reported language skills, we construct our measure of English language skills, where 3, 2, 1, and 0 correspond to speaks English "very well", "well", "not well", "not at all", respectively. To create our instrument for language skills, we use information on the country of birth and age at arrival of immigrants. ${ }^{6}$ The data on origin-country characteristics that we use in the section of robustness checks has been obtained from the following sources: The education datasets come from Barro \& Lee (2013), data on the degrees of democracy comes from Freedom House (1973), and all other country characteristics come from the World Development Indicators $2015 .^{7}$

\subsection{Sample}

Our empirical analysis is based on the sample of individuals in the LS dataset who (i) lived in England and Wales at the time of Census 2011, (ii) are childhood immigrants and (iii) are aged 20 or above at the time of Census 2011. Childhood immigrants are defined as individuals born outside of the UK who arrived in the UK for the first time at age 15 or before. At this age, we assume that immigrants did not make their own migration decisions but followed their parents or guardians who migrated to the UK. For the sample used for the analyses of educational outcomes, the minimum age restriction is raised to 25 in order to allow individuals enough time to complete their education. In our analysis of health outcomes, we also impose the maximum age restriction of age 60 to deal with a possible issue of selective mortality. In our analysis of fertility outcomes, our sample is restricted to females that have at least one child registered in the LBSM dataset.

In order to implement our identification strategy, we create two groups of immigrants: (i) Individuals born in countries where English is not an official language, and (ii) individuals born in countries where English is an official language and the predominant language spoken. ${ }^{8}$ The first group is our "treatment group" and the second group is our "control group". Note that individuals born in countries where English is an official language but not the predominant language spoken are excluded from our sample because it is not clear to what extent they were exposed to English prior to their arrival in the UK. This restriction implies that we are excluding from our sample some groups of immigrants who account for a significant proportion of immigrants in the UK,

\footnotetext{
${ }^{6}$ Age at arrival in the UK is derived from the date that a person last arrived to live in the UK and their age. Short visits away from the UK are not counted in determining the date that a person last arrived. The age of arrival is only applicable to usual residents who were not born in the UK and does not include usual residents born in the UK who have emigrated and since returned.

${ }^{7}$ The variables in the World Development Indicators were downloaded from http://data.worldbank.org/ data-catalog/world-development-indicators

${ }^{8}$ To categorise countries, we have used the World Almanac and Book of Facts 2011.
} 
such as those born in India and Pakistan. A list of the countries of birth of the immigrants in our sample can be found in Table A1 in the appendix.

Table 1 presents summary statistics separately for early- and late-arrivers in the UK. As can be seen in panel A, English language skills are not very different between early-arrivers coming from English- and non-English-speaking countries, but late-arrivers coming from nonEnglish-speaking countries present a lower level of English proficiency than late-arrivers coming from English-speaking countries. Table 1 also shows that the share of individuals coming from European and Commonwealth countries differs between our treatment and control groups; in particular, a large proportion of immigrants born in English-speaking countries come from Commonwealth countries, and a large proportion of immigrants born in non-English-speaking countries come from Europe. This is a noticeable difference from the case of US immigrants studied by, for example Bleakley \& Chin (2010), where a significant proportion of immigrants from non-English-speaking countries come from Mexico.

\section{Results}

We begin by estimating equation (1) using the OLS estimator. ${ }^{9}$ Table 2 reports the OLS estimates of the effect of English language proficiency on the social outcomes of childhood immigrants in England and Wales, after controlling for individual characteristics and country-of-birth and ageat-arrival fixed effects. Panels A to $\mathrm{C}$ of Table 2 present results for education, health and fertility outcomes, respectively. The sample in panel $\mathrm{C}$ is restricted to mothers.

Panel A shows that better language skills are positively correlated with the likelihood of obtaining a higher level of educational qualifications; in particular, better language skills are significantly associated with a lower probability of having no qualifications or having only compulsorylevel qualifications (rows 1 and 2), and are significantly associated with a higher probability of having a post-compulsory qualification and an academic degree (rows 3 and 4). Turning to health outcomes for adults, panel B indicates that better English proficiency is significantly correlated with better self-reported health (rows 1 and 2) and lower probabilities of reporting bad or very bad health and having long-term health problems (rows 3 and 4). Regarding fertility outcomes,

\footnotetext{
${ }^{9}$ Our measure of English language skills is an ordinal variable as described in Section 4.1. In addition to this ordinal measure, we construct a dummy variable that equals one if a person speaks English "very well", and zero otherwise. We define the dummy variable such that it takes the value one if a person speaks English "ver well" instead of "very well" or "well" because a significant proportion of individuals in our sample reported to speak English either "very well" or "well". Thus, if we construct a dummy variable that takes the value one if a person speaks English "very well" or "well", the vast majority of observations take the value one and the dummy variable has too little variation. We use the dummy variable that equals one if a person speaks English "very well" to take into account possible non-linear effects of language proficiency on social outcomes of immigrants. Table A1 in online appendix presents results. The results using this alternative measure of English language skills are qualitatively similar to our main results presented in this section.
} 
Table 1: Immigrant Characteristics

\begin{tabular}{|c|c|c|c|c|}
\hline & \multicolumn{2}{|c|}{ Arrived aged $0-8$} & \multicolumn{2}{|c|}{ Arrived aged 9-15 } \\
\hline & $\begin{array}{c}\text { Born in } \\
\text { English-speaking } \\
\text { country }\end{array}$ & $\begin{array}{c}\text { Born in } \\
\text { non-English-speaking } \\
\text { country }\end{array}$ & $\begin{array}{c}\text { Born in } \\
\text { English-speaking } \\
\text { country }\end{array}$ & $\begin{array}{c}\text { Born in } \\
\text { non-English-speaking } \\
\text { country }\end{array}$ \\
\hline \multicolumn{5}{|c|}{ A. Individual characteristics (All, aged 20 to 60) } \\
\hline $\begin{array}{l}\text { English proficiency, } \\
\text { ordinal measure }\end{array}$ & $\begin{array}{c}2.99 \\
(0.10)\end{array}$ & $\begin{array}{c}2.98 \\
(0.18)\end{array}$ & $\begin{array}{c}2.96 \\
(0.22)\end{array}$ & $\begin{array}{c}2.74 \\
(0.55)\end{array}$ \\
\hline Age & $\begin{array}{c}41.75 \\
(11.40)\end{array}$ & $\begin{array}{c}36.27 \\
(12.27)\end{array}$ & $\begin{array}{c}42.24 \\
(13.68)\end{array}$ & $\begin{array}{c}31.15 \\
(11.36)\end{array}$ \\
\hline Female & $\begin{array}{c}0.51 \\
(0.50)\end{array}$ & $\begin{array}{c}0.50 \\
(0.50)\end{array}$ & $\begin{array}{c}0.54 \\
(0.50)\end{array}$ & $\begin{array}{c}0.50 \\
(0.50)\end{array}$ \\
\hline White & $\begin{array}{c}0.65 \\
(0.48)\end{array}$ & $\begin{array}{c}0.72 \\
(0.45)\end{array}$ & $\begin{array}{c}0.27 \\
(0.45)\end{array}$ & $\begin{array}{c}0.42 \\
(0.49)\end{array}$ \\
\hline Black & $\begin{array}{c}0.16 \\
(0.37)\end{array}$ & $\begin{array}{c}0.07 \\
(0.25)\end{array}$ & $\begin{array}{c}0.39 \\
(0.49)\end{array}$ & $\begin{array}{c}0.22 \\
(0.41)\end{array}$ \\
\hline Asian & $\begin{array}{l}0.15 \\
(0.36)\end{array}$ & $\begin{array}{c}0.09 \\
(0.28)\end{array}$ & $\begin{array}{c}0.29 \\
(0.45)\end{array}$ & $\begin{array}{c}0.20 \\
(0.40)\end{array}$ \\
\hline Other single race & $\begin{array}{c}0.01 \\
(0.09)\end{array}$ & $\begin{array}{c}0.09 \\
(0.28)\end{array}$ & $\begin{array}{c}0.01 \\
(0.09)\end{array}$ & $\begin{array}{c}0.12 \\
(0.33)\end{array}$ \\
\hline Multiracial & $\begin{array}{c}0.03 \\
(0.18)\end{array}$ & $\begin{array}{c}0.04 \\
(0.19)\end{array}$ & $\begin{array}{c}0.04 \\
(0.19)\end{array}$ & $\begin{array}{c}0.04 \\
(0.19)\end{array}$ \\
\hline Commonwealth & $\begin{array}{c}0.68 \\
(0.47)\end{array}$ & $\begin{array}{c}0.04 \\
(0.20)\end{array}$ & $\begin{array}{c}0.82 \\
(0.39)\end{array}$ & $\begin{array}{c}0.04 \\
(0.18)\end{array}$ \\
\hline Europe & $\begin{array}{c}0.19 \\
(0.39)\end{array}$ & $\begin{array}{c}0.59 \\
(0.49)\end{array}$ & $\begin{array}{c}0.09 \\
(0.28)\end{array}$ & $\begin{array}{c}0.29 \\
(0.45)\end{array}$ \\
\hline \multicolumn{5}{|c|}{ B. Education (All, aged 25 and over) } \\
\hline No qualifications & $\begin{array}{c}0.12 \\
(0.33)\end{array}$ & $\begin{array}{c}0.11 \\
(0.32)\end{array}$ & $\begin{array}{c}0.20 \\
(0.40)\end{array}$ & $\begin{array}{c}0.24 \\
(0.43)\end{array}$ \\
\hline Compulsory & $\begin{array}{c}0.40 \\
(0.49)\end{array}$ & $\begin{array}{c}0.41 \\
(0.49)\end{array}$ & $\begin{array}{c}0.47 \\
(0.50)\end{array}$ & $\begin{array}{c}0.46 \\
(0.50)\end{array}$ \\
\hline Post-compulsory & $\begin{array}{c}0.60 \\
(0.49)\end{array}$ & $\begin{array}{c}0.59 \\
(0.49)\end{array}$ & $\begin{array}{c}0.53 \\
(0.50)\end{array}$ & $\begin{array}{c}0.53 \\
(0.50)\end{array}$ \\
\hline Academic degree & $\begin{array}{c}0.43 \\
(0.49)\end{array}$ & $\begin{array}{c}0.41 \\
(0.49)\end{array}$ & $\begin{array}{c}0.34 \\
(0.47)\end{array}$ & $\begin{array}{c}0.34 \\
(0.47)\end{array}$ \\
\hline
\end{tabular}


Table 1: Immigrant Characteristics - continued

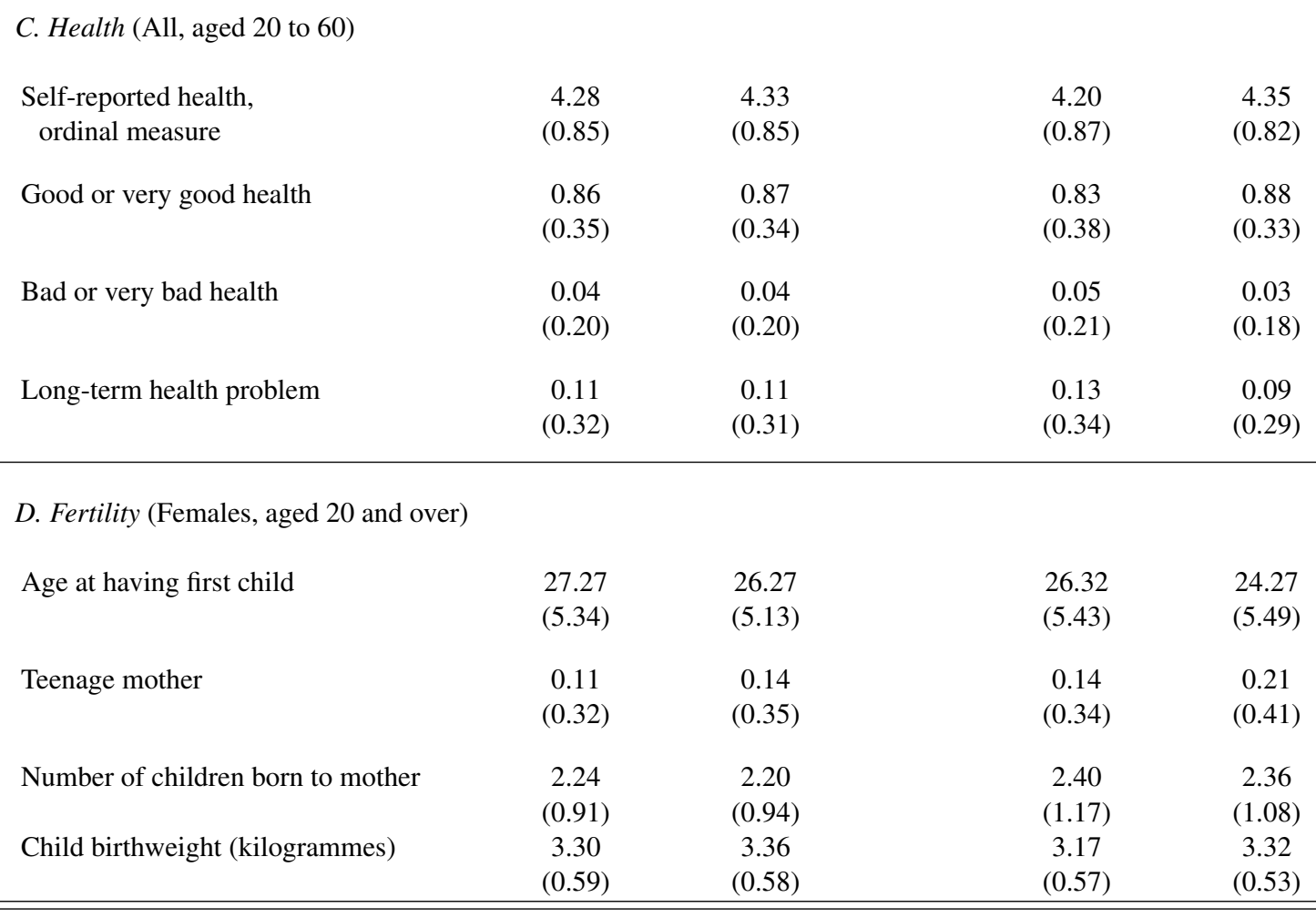

Notes: Standard deviations are shown in parenthesis. The sample consists of individuals in the ONS LS dataset who were present in the 2011 Census for England and Wales, are childhood immigrants, and were aged 20 to 60 (Panels A, C), 25 and over (panel B), or 20 and over (panel D) at Census 2011. Childhood immigrant is defined as those born outside of the UK who arrived in the UK at age 15 or earlier. Columns (1) and (2) present statistics for individuals who arrived in the UK at age eight or earlier, while columns (3) and (4) report statistics for those who arrived after age eight. The sample is divided into two groups: individuals born in countries where English is an official language and the predominant language spoken (columns (1) and (3)), and those born in countries where English is not an official language (columns (2) and (4)). Sample size varies by panel and column. Panels A and C contain 3,268; 2,879; 2,263 and 2,151 observations in columns (1) to (4), respectively. Panel B contains 3,414; 2,572; 2,489 and 1,536 observations per column. Sample sizes in panel D vary by outcome: birthweight of child $(1,866 ; 1,371 ; 1,152$, and 745 in columns (1) to (4), respectively), age at which a woman had her first child $(637 ; 444 ; 340 ; 212)$, whether the mother had her first child when she was in her teens $(1,017 ; 773 ; 681 ; 407)$, number of children a woman has given birth to $(712 ; 501 ; 425 ; 263)$.

Source: Authors' calculations based on the ONS England and Wales Longitudinal Study dataset. 
Table 2: OLS Estimates of the Effects of English Proficiency

\begin{tabular}{llcc}
\hline \hline \multirow{2}{*}{ Dependent variable: } & English proficiency & Standard errors \\
\hline \multirow{3}{*}{ A. Education } & No qualifications & $-0.266^{* * *}$ & $(0.02)$ \\
& Compulsory & $-0.214^{* * *}$ & $(0.02)$ \\
& Post-compulsory & $0.224^{* * *}$ & $(0.02)$ \\
& Academic degree & $0.218^{* * *}$ & $(0.02)$ \\
\hline \multirow{4}{*}{ B. Health } & Self-reported health & $0.360^{* * *}$ & $(0.04)$ \\
& Good or very good health & $0.117^{* * *}$ & $(0.02)$ \\
& Bad or very bad health & $-0.048^{* * *}$ & $(0.01)$ \\
& Long-term health problem & $-0.104^{* * *}$ & $(0.02)$ \\
\hline \multirow{4}{*}{ C. Fertility } & Age at having first child & $2.421^{* * *}$ & $(0.52)$ \\
& Teenage mother & $-0.116^{* * *}$ & $(0.03)$ \\
& Number of children & $-0.476^{* * *}$ & $(0.13)$ \\
& Child birthweight & 0.008 & $(0.03)$ \\
\hline \hline
\end{tabular}

Notes: $* * * p<.01, * * p<.05$, and $* p<.10$. Standard errors are clustered by country of birth. All regressions are estimated by OLS and include the following controls: Dummy variables for sex, race, age, age at arrival, and country of origin. Sample size varies by outcome: 10,010 individuals for the education outcomes; 10,561 for the health outcomes, and 1,$633 ; 2,878 ; 1,901$, and 5,134 females for each of the fertility outcomes, respectively.

Source: Authors' calculations based on the ONS England and Wales Longitudinal Study dataset. 
panel $\mathrm{C}$ shows that better English proficiency is significantly associated with a delay in the age at which women have their first child, a lower likelihood of becoming a teenage mother, and having fewer children (rows 1 to 3). However, English skills appear to have no significant association with child health measured by birthweight (row 4).

The problem with the OLS estimator of $\beta_{1}$ in equation (1) is that it will be biased if (i) unobserved heterogeneity across individuals that affects our social outcomes, such as ability and cultural attitude, is also correlated with fluency in English, (ii) immigrants' social outcomes and English skills are simultaneously determined or (iii) our English proficiency measure is correlated with measurement errors. To address this potential endogeneity of English skills, we estimate equation (1) using the IV estimator, where we use, as an instrument for English skills, the interaction of the excess age at arrival from age eight and a dummy variable for coming from non-English-speaking countries (see equation (2)). Table 3 presents the first-stage and reduced-form estimates of the effects of the instrument on English skills and social outcomes, respectively, and the IV estimates of the effects of English skills on the social outcomes (i.e., $\beta_{1}$ in equation (1)). Panels A to $\mathrm{C}$ correspond to the regressions for education, health and fertility outcomes, respectively.

The first-stage estimates presented in Panels A and B, column (1), indicate that, for those individuals born in non-English-speaking countries, each year past age eight at arrival significantly decreases their English language skill ordinal measure by approximately 0.04, on average. When the sample is restricted to mothers in panel $\mathrm{C}$, the coefficient estimates increase in absolute terms to -0.06 or -0.07 . It might be the case that females are more sensitive to age at arrival regarding English proficiency. The magnitude of the coefficient implies that a person's English ordinary measure would be approximately lower by half a unit if the person arrived from a non-Englishspeaking country at age 15 instead of at age eight.

Regarding educational outcomes, reported in panel A, the reduced-form estimates in column (2) show that, among immigrants from non-English-speaking countries, after age eight, each additional year that passes before they arrive in the UK increases their likelihood of having no qualifications (row 1) and decreases their likelihood of obtaining academic degrees (row 4). In line with the reduced-form estimates, the causal effects of interest reported in column (3) indicate that better English language skills significantly lower the probability of having no qualifications and raise that of obtaining academic degrees (rows 1 and 4). The point estimates suggest that a one-unit increase in English language skills lowers the probability of having no qualifications by 0.51 and raises that of obtaining academic degrees by 0.36 , both of which are sizable effects. Because understanding the language used at school is likely to be a key component of academic success, it is not surprising that individuals with better English skills have a higher level of educational attainment. Regarding the probabilities of obtaining compulsory- and 
Table 3: First-stage, Reduced-form, and IV Estimates

\begin{tabular}{|c|c|c|c|}
\hline \multirow[t]{3}{*}{ Dependent variable: } & English proficiency & \multicolumn{2}{|c|}{ Education, health or fertility } \\
\hline & First-stage & Reduced-form & IV \\
\hline & (1) & (2) & (3) \\
\hline
\end{tabular}

A. Education (All, aged 25 and over)

\begin{tabular}{|c|c|c|c|}
\hline No qualifications & $\begin{array}{c}-0.040 * * * \\
(0.01)\end{array}$ & $\begin{array}{c}0.020 * * * \\
(0.00)\end{array}$ & $\begin{array}{c}-0.507 * * * \\
(0.06)\end{array}$ \\
\hline Compulsory & $\begin{array}{c}-0.040 * * * \\
(0.01)\end{array}$ & $\begin{array}{l}0.006 \\
(0.00)\end{array}$ & $\begin{array}{l}-0.156 \\
(0.10)\end{array}$ \\
\hline Post-compulsory & $\begin{array}{c}-0.040 * * * \\
(0.01)\end{array}$ & $\begin{array}{l}-0.007 \\
(0.00)\end{array}$ & $\begin{array}{l}0.165 \\
(0.10)\end{array}$ \\
\hline Academic degree & $\begin{array}{c}-0.040 * * * \\
(0.01)\end{array}$ & $\begin{array}{c}-0.014 * * \\
(0.01)\end{array}$ & $\begin{array}{c}0.357 * * * \\
(0.13)\end{array}$ \\
\hline \multicolumn{4}{|l|}{ B. Health (All, aged 20 to 60 ) } \\
\hline $\begin{array}{l}\text { Self-reported health, } \\
\text { ordinal measure }\end{array}$ & $\begin{array}{c}-0.043 * * * \\
(0.01)\end{array}$ & $\begin{array}{l}-0.010 \\
(0.01)\end{array}$ & $\begin{array}{l}0.222 * \\
(0.12)\end{array}$ \\
\hline Good or very good health & $\begin{array}{c}-0.043^{* * * *} \\
(0.01)\end{array}$ & $\begin{array}{l}-0.003 \\
(0.00)\end{array}$ & $\begin{array}{l}0.065 \\
(0.05)\end{array}$ \\
\hline Bad or very bad health & $\begin{array}{c}-0.043 * * * \\
(0.01)\end{array}$ & $\begin{array}{l}0.000 \\
(0.00)\end{array}$ & $\begin{array}{r}-0.003 \\
(0.03)\end{array}$ \\
\hline Long-term health problem & $\begin{array}{c}-0.043 * * * \\
(0.01)\end{array}$ & $\begin{array}{l}-0.003 \\
(0.00)\end{array}$ & $\begin{array}{l}0.059 \\
(0.05)\end{array}$ \\
\hline \multicolumn{4}{|c|}{ C. Fertility (Females, aged 20 and over) } \\
\hline Age at having first child & $\begin{array}{c}-0.057 * * * \\
(0.02)\end{array}$ & $\begin{array}{c}-0.193 * * \\
(0.09)\end{array}$ & $\begin{array}{c}3.361^{* *} \\
(1.66)\end{array}$ \\
\hline Teenage mother & $\begin{array}{c}-0.070 * * * \\
(0.01)\end{array}$ & $\begin{array}{c}0.015^{* *} \\
(0.01)\end{array}$ & $\begin{array}{c}-0.222 * * \\
(0.09)\end{array}$ \\
\hline Number of children & $\begin{array}{c}-0.065^{* * * *} \\
(0.02)\end{array}$ & $\begin{array}{c}0.050 * * \\
(0.02)\end{array}$ & $\begin{array}{c}-0.771 * * \\
(0.34)\end{array}$ \\
\hline $\begin{array}{l}\text { Child birthweight } \\
\text { (kilogrammes) }\end{array}$ & $\begin{array}{c}-0.074 * * * \\
(0.02)\end{array}$ & $\begin{array}{l}0.004 \\
(0.01)\end{array}$ & $\begin{array}{l}-0.047 \\
(0.10)\end{array}$ \\
\hline
\end{tabular}

Notes: $* * * p<.01, * * p<.05$, and $* p<.10$. Standard errors are clustered by country of birth. First-stage and reduced-form estimates are the estimated coefficients on the interaction of age at arrival with and an indicator for coming from non-Englishspeaking countries. The IV estimates are the estimates of $\beta_{1}$ in equation (1). Rows in each panel correspond to regressions for different outcomes of education, health and fertility. Refer to Table 2 for the controls included and sample sizes.

Source: Authors' calculations based on the ONS England and Wales Longitudinal Study dataset. 
post-compulsory-level qualifications, the IV estimates in rows 2 and 3 are insignificant. Taken together, our findings suggest that proficiency in English affects the likelihood of having the highest and the lowest levels of educational attainment (i.e., no qualifications and academic degrees), but has no effect on the likelihood on the educational attainment at an intermediate level.

Turning to health outcomes for adults reported in panel B, the reduced-form estimates show that arriving after age eight has no significant effect on any of the self-reported health measures we analyse. The IV estimates presented in column (3) also show insignificant effects of English skills, with the exception of the effect on the self-reported ordinal measure, which is significant at the 10 percent level. Panel $\mathrm{C}$ reports fertility outcomes. The reduced-form estimates presented in column (2) show that, for each year at arrival past age eight, the age at which the mother has her first child significantly decreases (row 1), and both the probabilities of becoming a teenage mother and the number of children a mother gives birth to significantly increase (rows 2 and 3). The causal effects of interest presented in column (3) show that a one-unit increase in English skills significantly raises the mother's age at having first child by approximately 3.4 years (row 1), and significantly lower her likelihood of becoming a teenage mother by approximately 0.22 (row 2). In addition to the timing of having a child, English proficiency also affects the number of children a woman gives birth to: a one-unit increase in our English skill measure significantly reduces the number of children by approximately 0.77 (row 3). This is a sizable effect corresponding to a reduction of approximately 33 per cent relative to the mean value for childhood immigrants who arrived after age eight from non-English-speaking countries. We do not find any effect of English skills on child health measured by his birthweight.

When comparing OLS and IV estimates, our general findings are that OLS estimates are greater in absolute terms for health outcomes, while IV estimates tend to be greater in absolute terms for education and fertility outcomes. For example, the IV estimate is almost double the size of the OLS estimate for the probability of having no qualifications (see panels A of Tables 2 and 3). It is possible that unobserved individual characteristics, such as ability, biases the OLS estimator upward, but at the same time measurement errors possibly correlated with our language proficiency measures bias the OLS estimator downward. If the downward bias caused by measurement errors outweighs the upward bias caused by unobserved heterogeneity, IV estimates can be greater than OLS estimates. See Bleakley \& Chin (2004) for further technical discussions. Regarding health outcomes, they are only outcomes that are self-reported unlike education and fertility outcomes for which we use more objective measures. If a person is lenient in self-assessment, it is possible that the person reports to have a better health and a better English language proficiency compared to a person who is more strict in self-assessment. If this is the case, the leniency contained in the error term of equation (1) can cause upward bias in the OLS estimator of the effects of English skills, possibly leading to greater OLS estimates relative 
to IV estimates (in absolute terms).

\subsection{Mechanisms at Work}

We have found that better English skills significantly affect the education and fertility outcomes of immigrants born in non-English-speaking countries. In this subsection, we explore a possible mechanism through which language affects fertility: Education. In order to do so, we control for measures of education, in addition to English proficiency, in our fertility regressions. It might be the case that better English skills improve the educational attainment and career opportunities of women, which could in turn delay the age at which they have their first child or reduce the number of children they have because, for example, their opportunity cost of having children increases. As measures of education, we include a set of dummy variables that equal one if the person has no qualifications, a post-compulsory qualification and an academic degree, respectively, and zero otherwise. Our reference group is women with compulsory education. A caveat is that estimates of the effects of English proficiency on fertility outcomes no longer have causal interpretations in our regressions because education is likely endogenous. Despite this limitation, we present these results as suggestive evidence of a possible role that education plays in determining fertility outcomes.

Even-numbered columns in Table 4 present the effects of English proficiency on the age at which a woman has her first child, the probability of becoming a mother in her teens, the number of children she gives birth to, and her children's birthweight, respectively, after controlling for education. For comparison purposes, we present the base results from Table 3 without controlling for education in adjacent odd-numbered columns. Column (2) shows that the point estimate of the effect of English skills on age at having first child is greatly reduced by nearly 64 per cent relative to the corresponding estimate in column (1), and is no longer statistically significant. In contrast, education significantly affects the timing of having children. For example, relative to individuals with compulsory-level qualifications, women with no qualifications and academic degrees have their first child approximately 2.0 years earlier and 2.3 years later, respectively (see column (2)). Turning to the likelihood of becoming a teenage mother, column (4) shows that the point estimate is lowered by 21 per cent (cf., column (3)). Similar results hold for the regression on the number of children a woman has: After controlling for education, the effect of English skills becomes insignificant (column (6)). These results provide some evidence in favour of the argument that education could be a key channel through which English proficiency affects the fertility decisions of immigrant women. Namely, an improvement in language skills results in a higher educational attainment, which could in turn delay the age at which a woman has her first child and reduce the number of children she has. This is a plausible mechanism as is shown by, for example, Black et al. (2008) who found that increased educational attainment reduced 
Table 4: The Effects of English Proficiency and Education on Fertility

\begin{tabular}{|c|c|c|c|c|c|c|c|c|}
\hline \multirow[t]{2}{*}{ Dependent variable: } & \multicolumn{2}{|c|}{$\begin{array}{l}\text { Age at having } \\
\text { first child }\end{array}$} & \multicolumn{2}{|c|}{ Teenage mother } & \multicolumn{2}{|c|}{ Number of children } & \multicolumn{2}{|c|}{ Child birthweight } \\
\hline & (1) & (2) & (3) & (4) & (5) & (6) & (7) & (8) \\
\hline English skills & $\begin{array}{c}3.361 * * \\
(1.66)\end{array}$ & $\begin{array}{l}1.211 \\
(1.65)\end{array}$ & $\begin{array}{c}-0.222 * * \\
(0.09)\end{array}$ & $\begin{array}{c}-0.175^{*} \\
(0.10)\end{array}$ & $\begin{array}{c}-0.771 * * \\
(0.34)\end{array}$ & $\begin{array}{l}-0.579 \\
(0.37)\end{array}$ & $\begin{array}{l}-0.047 \\
(0.10)\end{array}$ & $\begin{array}{c}-0.100 \\
(0.11)\end{array}$ \\
\hline No qualifications & & $\begin{array}{c}-1.971 * * * \\
(0.71)\end{array}$ & & $\begin{array}{l}0.063 * \\
(0.03)\end{array}$ & & $\begin{array}{c}0.308 * * \\
(0.13)\end{array}$ & & $\begin{array}{l}-0.066 \\
(0.05)\end{array}$ \\
\hline Post-compulsory & & $\begin{array}{l}0.492 \\
(0.40)\end{array}$ & & $\begin{array}{c}-0.053 * * \\
(0.02)\end{array}$ & & $\begin{array}{l}-0.022 \\
(0.06)\end{array}$ & & $\begin{array}{l}-0.009 \\
(0.03)\end{array}$ \\
\hline Academic degree & & $\begin{array}{l}2.275^{* * * *} \\
(0.34)\end{array}$ & & $\begin{array}{l}-0.044 * * * \\
(0.02)\end{array}$ & & $\begin{array}{l}-0.066 \\
(0.06)\end{array}$ & & $\begin{array}{c}0.095^{* * * *} \\
(0.03)\end{array}$ \\
\hline $\begin{array}{l}\text { Education controls } \\
\text { \# Observations }\end{array}$ & $\begin{array}{c}\text { no } \\
1,633\end{array}$ & $\begin{array}{c}\text { yes } \\
1,633\end{array}$ & $\begin{array}{c}\text { no } \\
2,878\end{array}$ & $\begin{array}{c}\text { yes } \\
2,878\end{array}$ & $\begin{array}{c}\text { no } \\
1,901\end{array}$ & $\begin{array}{c}\text { yes } \\
1,901\end{array}$ & $\begin{array}{c}\text { no } \\
5,134\end{array}$ & $\begin{array}{c}\text { yes } \\
5,134\end{array}$ \\
\hline
\end{tabular}

Notes: $* * * p<.01, * * p<.05$, and $* p<.10$. Standard errors are clustered by country of birth. Estimates in the first row are the estimates of $\beta_{1}$ in equation (1). All regressions include the controls specified in Table 2. In addition, all even-numbered columns include dummy variables for having no qualifications, a post-compulsory qualification and an academic degree.

Source: Authors' calculations based on the ONS England and Wales Longitudinal Study dataset. 
teenage fertility. Our results are different from the findings of Bleakley \& Chin (2010) who find that the effects of language proficiency remain significant even after controlling for measures of education based on US data. This difference could suggest that the mechanisms through which English skills affect the fertility outcomes of immigrant women are different in the UK and the US .

\section{Robustness Checks}

We now turn to address the concern that our main results are driven by differences in background characteristics of immigrants born in English- and non-English-speaking countries. First, we will address the concern that our results could be driven by differences in parental characteristics. Second, we will address the concern that immigrants born in English- and non-English-speaking countries could be different in other aspects, aside from language, that could also affect their social outcomes. To address this latter concern, we will employ two different strategies: (i) We consider different sample specifications in which samples are restricted to immigrants born in countries that are likely to be less heterogeneous, and (ii) we control for an interaction of age at arrival with different origin-country characteristics.

First, parental characteristics that affect the social outcomes of immigrants may be different between the two sets of immigrants, and parents with different characteristics may make different decisions regarding their timing of immigration. For example, parents of immigrants from non-English-speaking countries may decide to migrate to the UK when their children are relatively young to make it easier for their children to adapt to the new environment. If this was the case, our IV estimator would be biased. To empirically examine this possibility, we regress age at arrival on a dummy variable for coming from non-English-speaking countries and a full set of controls. The estimated coefficient on the indicator for coming from a non-Englishspeaking country is equal to 0.44 with p-value 0.42 , indicating that the result does not support the possibility that childhood immigrants from English- and non-English-speaking countries are systematically arriving in the UK at different ages.

Next, we explicitly control for parental characteristics measured by the highest level of education attained by any of the two parents of the individuals in our sample. To the best of our knowledge, this is the first paper that controls for parental education in the analyses of the causal effects of English skills on education and health outcomes. A limitation of this approach is that sample sizes are diminished and become 6,137 and 7,675 observations for education and health outcomes, respectively, due to missing values in the data on parental education. For fertility outcomes, we cannot calculate IV estimates because first-stage estimates become insignificant in smaller sample. Despite this limitation, we present results for education and health regressions 
Table 5: The Effects of English Proficiency after Controlling for Parental Education

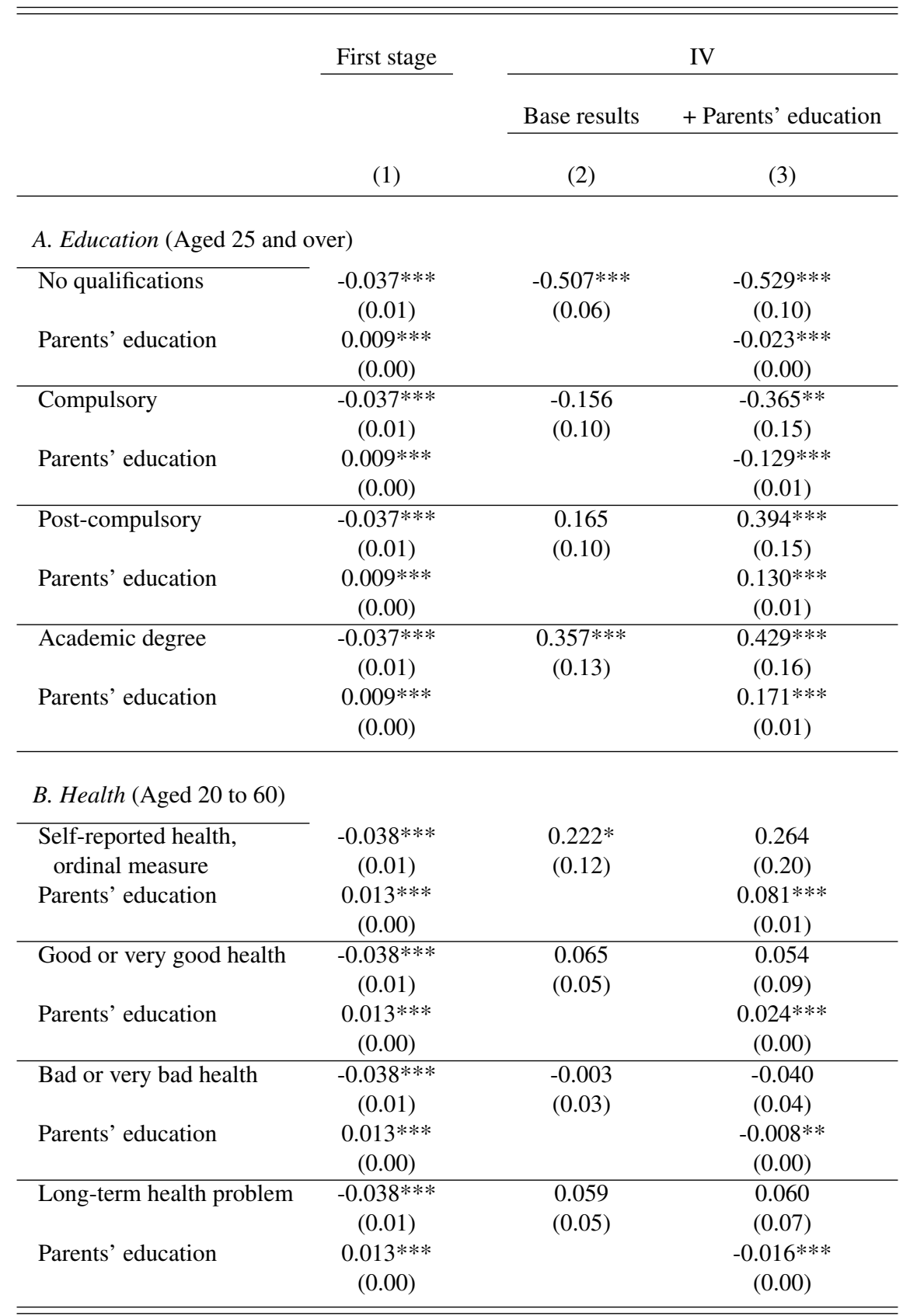

Notes: $* * * p<.01, * * p<.05$, and $* p<.10$. Standard errors are clustered by country of birth. First-stage and reduced-form estimates are the estimated coefficients on the interaction of age at arrival and coming from non-English-speaking countries. The IV estimates are the estimates of $\beta_{1}$ in equation (1). Rows in each panel correspond to regressions for different outcomes of education and health, where sample sizes are 6,137 and 7,675 observations, respectively. Refer to Table 2 for the controls included.

Source: Authors' calculations based on the ONS England and Wales Longitudinal Study dataset. 
with parental education as a control in Table 5 to examine a possible role that parental education plays in explaining the effects of English skills on the social outcomes of childhood immigrants. The first-stage estimates presented in column (1) are not sensitive to the inclusion of parental education. The IV estimates reported in column (3) show that the results are qualitatively very similar to our base results from the previous section (see column (2)). An interesting difference that we find is that the effects of English skills on the likelihoods of having compulsory- and post-compulsory-level qualifications become significant, indicating that an improvement in English skills significantly reduces the likelihood of having compulsory-level qualifications as the highest level of qualifications obtained and raises that of having post-compulsory-level qualifications. To examine whether these results are induced by a change in sample sizes or by the fact that we control for parental education, we run regressions using these restricted samples but without controlling for parental characteristics. Estimates (not reported) are not significantly different from those reported in Table 5, confirming that English proficiency significantly affects educational outcomes of immigrants even after accounting for parental characteristics.

We now address another important concern in our model. A key assumption in our IV strategy to identify the causal effects of language skills is that immigrants from English- and nonEnglish-speaking countries are exposed to the same age-at-arrival effects aside from language. Under this assumption, immigrants coming from English-speaking countries can be used to partial out age-at-arrival effects that immigrants from non-English-speaking countries are exposed to. However, it could be reasonable to doubt the validity of this assumption; for example, it could be that English-speaking countries are economically, culturally, and institutionally more similar to the UK, making this age-at-arrival effects differ between immigrants from the two groups of countries. These different effects will be absorbed by country-of-origin fixed effects in equation (1) if these effects that are specific to country-of-origin do not vary across age at arrival. But these country-of-origin specific effects could vary across age at arrival; for example, for those who arrive in the UK at an early age, country-of-origin specific characteristics may not affect their social outcomes in the UK because they left their origin countries sufficiently early not to be affected by their characteristics. In contrast, late-arrivers may be affected by their origin-country's characteristics more intensively, because they lived in their countries of birth for a longer period of time. This type of concerns might be less severe in the UK context than in the US context as the average characteristics of immigrants from the two groups of countries might be more similar in the case of UK immigrants. For example, OECD (2012) reports that $47 \%$ of UK immigrants are highly educated, compared to $34 \%$ in the US, and $34 \%$ of UK immigrants come from an OECD high-income country, compared to only $14 \%$ for US immigrants.

Nevertheless, to address this concern, our first approach is to retain in our sample only immigrants from countries that may be less heterogeneous from each other. In particular, we exclude 
from our sample immigrants from Europe and Commonwealth countries in columns (2) and (3) of Table 6, respectively, and we present our base results in column (1) for comparison purposes. A limitation of this approach is that, due to relatively small sample sizes of fertility regressions, first-stage estimates are not strong enough to compute the IV estimates when we diminish sample sizes. Thus, we report results only for education and health outcomes for which sample sizes are large enough even when we omit a subset of countries from our samples. The European countries have close economic and political ties and cultural similarities with the UK due to, for example, the existence of the European Union and a long history of economic, political and cultural interactions. Likewise, Commonwealth countries also share some commonalities with the UK regarding, for example, culture and legal systems. Omitting immigrants from these countries that have special ties with the UK may make the two groups of countries less heterogeneous.

The results for educational outcomes (see panel A) are qualitatively similar to our main findings, although several interesting differences arise. After restricting the sample, the effect of English language proficiency generally increases in magnitude in absolute terms. Furthermore, the effect on the probabilities of having compulsory- and post-compulsory-level qualifications become significant, implying that English language proficiency has a greater impact in the case of immigrants who come from countries that might be less similar to the UK than European and Commonwealth countries. A possible interpretation of this result is that culture and the educational systems in Europe and Commonwealth countries might have a greater similarity to those in the UK, making it easier for immigrants from these countries to adapt to the UK system irrespective of their proficiency in English. The results we obtain for our health and fertility outcomes -reported in panels B and C, respectively-, are also qualitatively similar to our base results.

In a similar vein, to make our samples more homogeneous in terms of income level, we divide our sample into immigrants coming from countries with high and low gross domestic product (GDP) per capita. Origin-country GDP per capita could reflect numerous aspects of origincountries that potentially affect immigrants' social outcomes. For example, high GDP countries may, on average, have better educational and healthcare systems, a higher life expectancy, and fewer children per family, and all these characteristics may affect the social outcomes of the immigrants in our sample. Columns (4) and (5) of Table 6 present results for immigrants coming from below-median and above-median GDP countries, respectively. The results are qualitatively similar to our base results, although we observe an interesting difference. Namely, we find that the significant effect of English language proficiency on the likelihood of having academic degrees is driven by immigrants born in high GDP countries. A possible interpretation of this finding is that immigrants born in low GDP countries may have lower expectations of future jobs, for example, after observing the jobs of their parents, which may in turn affect their willingness 
Table 6: IV Estimates using Alternative Sample Specifications

\begin{tabular}{|c|c|c|c|c|c|}
\hline & All & No Europe & $\begin{array}{l}\text { No Common } \\
\text {-wealth }\end{array}$ & Low GDP & High GDP \\
\hline & (1) & (2) & (3) & (4) & (5) \\
\hline \multicolumn{6}{|c|}{ A. Education (Aged 25 and over) } \\
\hline No qualifications & $\begin{array}{c}-0.507 * * * \\
(0.06)\end{array}$ & $\begin{array}{c}-0.467 * * * \\
(0.07)\end{array}$ & $\begin{array}{c}-0.497 * * * \\
(0.07)\end{array}$ & $\begin{array}{c}-0.335^{* * *} \\
(0.08)\end{array}$ & $\begin{array}{c}-0.579 * * * \\
(0.10)\end{array}$ \\
\hline Compulsory & $\begin{array}{c}-0.156 \\
(0.10)\end{array}$ & $\begin{array}{c}-0.230^{*} \\
(0.13)\end{array}$ & $\begin{array}{c}-0.216^{* *} \\
(0.09)\end{array}$ & $\begin{array}{l}-0.084 \\
(0.24)\end{array}$ & $\begin{array}{l}-0.187 \\
(0.12)\end{array}$ \\
\hline Post-compulsory & $\begin{array}{l}0.165 \\
(0.10)\end{array}$ & $\begin{array}{l}0.246^{*} \\
(0.13)\end{array}$ & $\begin{array}{c}0.228 * * \\
(0.09)\end{array}$ & $\begin{array}{l}0.110 \\
(0.24)\end{array}$ & $\begin{array}{l}0.189 \\
(0.12)\end{array}$ \\
\hline Academic degree & $\begin{array}{c}0.357 * * * \\
(0.13)\end{array}$ & $\begin{array}{c}0.398 * * * \\
(0.15)\end{array}$ & $\begin{array}{c}0.469 * * * \\
(0.12)\end{array}$ & $\begin{array}{l}0.240 \\
(0.26)\end{array}$ & $\begin{array}{c}0.375^{* *} \\
(0.16)\end{array}$ \\
\hline \multicolumn{6}{|l|}{ B. Health (Aged 20 to 60) } \\
\hline $\begin{array}{l}\text { Self-reported health, } \\
\text { ordinal measure }\end{array}$ & $\begin{array}{l}0.222^{*} \\
(0.12)\end{array}$ & $\begin{array}{l}0.157 \\
(0.11)\end{array}$ & $\begin{array}{c}0.263^{*} \\
(0.16)\end{array}$ & $\begin{array}{l}0.205 \\
(0.15)\end{array}$ & $\begin{array}{l}0.101 \\
(0.23)\end{array}$ \\
\hline Good or very good health & $\begin{array}{l}0.065 \\
(0.05)\end{array}$ & $\begin{array}{l}0.036 \\
(0.05)\end{array}$ & $\begin{array}{l}0.108 \\
(0.07)\end{array}$ & $\begin{array}{l}0.064 \\
(0.06)\end{array}$ & $\begin{array}{l}0.009 \\
(0.09)\end{array}$ \\
\hline Bad or very bad health & $\begin{array}{l}-0.003 \\
(0.03)\end{array}$ & $\begin{array}{l}-0.003 \\
(0.02)\end{array}$ & $\begin{array}{l}-0.007 \\
(0.04)\end{array}$ & $\begin{array}{l}-0.002 \\
(0.03)\end{array}$ & $\begin{array}{l}0.023 \\
(0.05)\end{array}$ \\
\hline Long-term health problem & $\begin{array}{l}0.059 \\
(0.05)\end{array}$ & $\begin{array}{l}0.049 \\
(0.05)\end{array}$ & $\begin{array}{l}0.039 \\
(0.06)\end{array}$ & $\begin{array}{l}0.098 \\
(0.06)\end{array}$ & $\begin{array}{l}0.051 \\
(0.10)\end{array}$ \\
\hline
\end{tabular}

Notes: *** $p<.01, * * p<.05$, and $* p<.10$. Standard errors are clustered by country of birth. The estimates shown are the IV estimates of $\beta_{1}$ in equation (1), using the controls specified in Table 2 . The results shown in columns (1) to (3) correspond to different sample specifications: Full sample (column (1)), sample excluding Europe (column (2)), sample excluding Commonwealth countries (column (3)), individuals born in low GDP countries (column (4)), and individuals born in high GDP countries (column (5)). Sample size varies by column: for education outcomes, 10,010, 6,329, 5,914, 3,980, and 6,030 observations; and for health outcomes, 10,561, 7,440, 6,307, 4,889, and 5,672 observations in columns (1) to (5), respectively.

Source: Authors' calculations based on the ONS England and Wales Longitudinal Study dataset. 
to obtain academic degrees, or it could be the case that immigrants from low GDP countries can not afford cost of education in British universities irrespective of their proficiency in English.

We now take a different approach to address the concern that immigrants from English- and non-English-speaking countries are exposed to different non-language age-at-arrival effects, by controlling for interactions of age at arrival with various origin-country characteristics. Unless otherwise stated, we use origin-country characteristics in $1970 .{ }^{10}$ Results are summarised in Table 7, where base results are presented in column (1) for comparison purposes. We begin by discussing our results for education outcomes reported in panel A. Column (2) controls for an interaction of age at arrival with country-of-origin average years of schooling. If non-Englishspeaking countries have, on average, a shorter (or longer) average number of years of schooling than English-speaking countries and the effects of origin-country average years of schooling vary by age at arrival, our instrument for English skills would capture the compound effects of language proficiency and differential average years of schooling in the origin country. In a similar spirit, column (3) controls for an interaction with origin-country pupil-teacher ratio in secondary education. Columns (2) and (3) indicate that coefficient estimates of the effects of English skills tend to be smaller than the base results, although the effect on the likelihood of having no qualifications remains significant at a one per cent level. In column (4), we control for an interaction with origin-country degrees of democracy. ${ }^{11}$ It could be the case that Englishspeaking countries are generally more (or less) democratic and that immigrants coming from those countries find it easier (harder) to adapt to a democratic country, such as the UK. Column (4) shows that our results are not sensitive to the inclusion of this additional variable.

Turning to health outcomes, panel B of Table 7 controls for interactions with per capita health expenditure, life expectancy, and degrees of democracy in the country of origin, respectively columns (2) to (4). Note that the data used for per capita health expenditure is from 1995, the earliest year for which data is available. We find that the effect of English skills largely remains insignificant after including these additional controls. Fertility outcomes are summarised in panel C. Column (2) controls for an interaction with origin-country total fertility rates, while column (3) controls for an interaction with origin-country adolescent fertility rates defined as the number of births per 1,000 women aged between 15 to 19. Our results are generally not sensitive to the inclusion of these additional variables. A difference to be noted is that standard errors of the effect of English skills on the number of children a mother has increase and the effect is now imprecisely estimated (column (2)). However, the point estimate is not significantly different

\footnotetext{
${ }^{10}$ The year 1970 is chosen because the average age of immigrants in our sample is 41 as of 2011 ; i.e., the average immigrant in our sample was born around 1970. We also considered using the values for 1980 (i.e., a decade after the time of birth of the average immigrant in our sample). Our results are not sensitive to the choice of the year.

${ }^{11}$ Degrees of democracy are measured by a democracy indicator, that ranges between "free", "partly free" and "not free", to which we assigned values 2,1 and 0, respectively. The data in 1972 is used as it is the earliest year for which data can be obtained.
} 
Table 7: IV Estimates using Alternative Controls for Origin-country Characteristics

\begin{tabular}{|c|c|c|c|c|}
\hline & \multirow{2}{*}{$\begin{array}{c}\text { Base results } \\
\text { (1) }\end{array}$} & \multicolumn{3}{|c|}{ Control for country of origin characteristics ( $\mathrm{x}$ age at arrival) } \\
\hline & & (2) & (3) & (4) \\
\hline A. Education & & Years of education & Pupil-teacher ratio & Democracy indicator \\
\hline No qualifications & $\begin{array}{c}-0.507 * * * \\
(0.06)\end{array}$ & $\begin{array}{c}-0.382 * * * \\
(0.12)\end{array}$ & $\begin{array}{c}-0.315^{* * * *} \\
(0.12)\end{array}$ & $\begin{array}{c}-0.512 * * * \\
(0.07)\end{array}$ \\
\hline Compulsory & $\begin{array}{c}-0.156 \\
(0.10)\end{array}$ & $\begin{array}{l}-0.061 \\
(0.19)\end{array}$ & $\begin{array}{l}0.113 \\
(0.22)\end{array}$ & $\begin{array}{r}-0.180 \\
(0.11)\end{array}$ \\
\hline Post-compulsory & $\begin{array}{l}0.165 \\
(0.10)\end{array}$ & $\begin{array}{l}0.080 \\
(0.19)\end{array}$ & $\begin{array}{l}-0.101 \\
(0.22)\end{array}$ & $\begin{array}{l}0.191 * \\
(0.11)\end{array}$ \\
\hline Academic degree & $\begin{array}{c}0.357 * * * \\
(0.13)\end{array}$ & $\begin{array}{l}0.253 \\
(0.22) \\
\end{array}$ & $\begin{array}{l}0.105 \\
(0.26) \\
\end{array}$ & $\begin{array}{c}0.329 * * \\
(0.14) \\
\end{array}$ \\
\hline B. Health & & Health expenditure & Life expectancy & Democracy indicator \\
\hline $\begin{array}{l}\text { Self-reported health, } \\
\text { ordinal measure }\end{array}$ & $\begin{array}{l}0.222 * \\
(0.12)\end{array}$ & $\begin{array}{l}-0.045 \\
(0.19)\end{array}$ & $\begin{array}{l}0.205 \\
(0.15)\end{array}$ & $\begin{array}{c}0.295^{* *} \\
(0.12)\end{array}$ \\
\hline $\begin{array}{l}\text { Good or very good } \\
\text { health }\end{array}$ & $\begin{array}{l}0.065 \\
(0.05)\end{array}$ & $\begin{array}{l}-0.036 \\
(0.07)\end{array}$ & $\begin{array}{l}0.030 \\
(0.06)\end{array}$ & $\begin{array}{l}0.088 \\
(0.06)\end{array}$ \\
\hline $\begin{array}{l}\text { Bad or very bad } \\
\text { health }\end{array}$ & $\begin{array}{l}-0.003 \\
(0.03)\end{array}$ & $\begin{array}{l}0.044 \\
(0.04)\end{array}$ & $\begin{array}{l}0.019 \\
(0.03)\end{array}$ & $\begin{array}{l}-0.008 \\
(0.03)\end{array}$ \\
\hline $\begin{array}{l}\text { Long-term } \\
\text { health problem }\end{array}$ & $\begin{array}{l}0.059 \\
(0.05) \\
\end{array}$ & $\begin{array}{l}0.109 \\
(0.08) \\
\end{array}$ & $\begin{array}{l}0.067 \\
(0.06) \\
\end{array}$ & $\begin{array}{l}0.061 \\
(0.06) \\
\end{array}$ \\
\hline C. Fertility & & Fertility rate & Adolescent fertility rate & Democracy indicator \\
\hline $\begin{array}{l}\text { Age at having } \\
\text { first child }\end{array}$ & $\begin{array}{c}3.361 * * \\
(1.66)\end{array}$ & $\begin{array}{l}3.300 \\
(2.17)\end{array}$ & $\begin{array}{l}3.204 * \\
(1.72)\end{array}$ & $\begin{array}{l}3.024 * \\
(1.60)\end{array}$ \\
\hline Teenage mother & $\begin{array}{c}-0.222 * * \\
(0.09)\end{array}$ & $\begin{array}{c}-0.207 * * \\
(0.09)\end{array}$ & $\begin{array}{c}-0.206 * * \\
(0.09)\end{array}$ & $\begin{array}{c}-0.189^{*} \\
(0.10)\end{array}$ \\
\hline Number of children & $\begin{array}{c}-0.771 * * \\
(0.34)\end{array}$ & $\begin{array}{c}-0.568 \\
(0.39)\end{array}$ & $\begin{array}{c}-0.695 * * \\
(0.35)\end{array}$ & $\begin{array}{c}-0.672 * * \\
(0.33)\end{array}$ \\
\hline $\begin{array}{l}\text { Birthweight of child } \\
\text { (kilogrammes) }\end{array}$ & $\begin{array}{l}-0.047 \\
(0.10)\end{array}$ & $\begin{array}{l}-0.063 \\
(0.12)\end{array}$ & $\begin{array}{l}-0.049 \\
(0.10)\end{array}$ & $\begin{array}{l}-0.049 \\
(0.10)\end{array}$ \\
\hline
\end{tabular}

Notes: $* * * p<.01, * * p<.05$, and $* p<.10$. Standard errors are clustered by country of birth. The estimates shown are the IV estimates of $\beta_{1}$ in equation (1) for the outcomes indicated in each row, using the controls specified in Table 2 and the additional control for origin-country characteristics specified in each column. Column 1 presents the base results. Columns 2 to 4 present results including an additional control each, which is the interaction of age at arrival with an origin-country characteristic, measured in 1970. For the education outcomes (panel A), this origin-country characteristics are: average years of education (column 2), pupil-teacher ratio in secondary school (column 3), and a democracy indicator (column 4); for health outcomes (panel B), per capita health expenditure in 1995 (column 2), life expectancy in 1970 (column 3), and the democracy indicator (column 4); for fertility outcomes (panel C), total fertility rate (column 2), infant mortality rate (column 3), and the democracy indicator (column 4). Sample size varies by specification.

Source: Authors' calculations based on the ONS England and Wales Longitudinal Study dataset. 
from our base result. Finally, our results are not sensitive to the inclusion of an interaction with our democracy indicator (column(4)).

\section{Conclusion}

Policy at present stresses that English proficiency is a key to the integration of immigrants in the UK, but there is little research evidence on how English skills affect social outcomes of the immigrant population in the UK. From an international perspective, the UK is a particularly interesting country for studying the phenomenon of assimilation because the immigrants composition in the UK is very different from that of the US, the country that has been most extensively studied: $47 \%$ of the immigrants in the UK come from a country with English as an official language, compared to $20 \%$ in the US; $47 \%$ of UK immigrants are highly educated, compared to $34 \%$ in the US; and $34 \%$ of UK immigrants come from an OECD high-income country, compared to only $14 \%$ of US immigrants.

In this paper, we study how English language skills affect education, health and fertility outcomes of childhood immigrants in England and Wales, using a unique dataset that links individual-level data from the 2011 Census for England and Wales and the LBSM. We study the causal effect of language skills using an IV estimation strategy where an interaction of age at arrival in the UK with an indicator for coming from non-English-speaking countries is used as an instrument for English skills. The idea of using age at arrival to construct the instrument is based on the critical period of language acquisition hypothesis, stating that a person exposed to a language within the critical period of language acquisition (i.e., childhood) learns the language more easily. The hypothesis implies that immigrants born in non-English-speaking countries who arrive in the UK at a young age will have on average better English language skills than those who arrive in the UK at an older age.

Our IV estimation results suggest that the educational achievement and fertility of immigrants are influenced by their ability to speak English. We find that better English language skills significantly raise the likelihood of having academic degrees and reduce that of having no qualifications. We also find that being proficient in English significantly delays the age at which an immigrant woman has her first child, lowers the likelihood of becoming a teenage mother, decreases the number of children a woman gives birth to, but has no effect on child health measured by birthweight. Supplementary regressions to explore the role that education plays to determine fertility outcomes of immigrants suggest that higher educational attainment as a result of better English language skills is a possible channel though which English proficiency delays the age at which a woman has her first child and reduces the number of children a woman has. This finding is different from that obtained by Bleakley \& Chin (2010) for the case of the US, where they find 
that language skills significantly affect the number of children living in same household even after controlling for education. This difference could suggest that the mechanism through which language skills affect the fertility choices may be different in the UK and US.

Our results have important policy implications. First, giving support to immigrants to learn and improve their English language skills may allow them to make the best of their education in school and further studies. This in turn may improve their educational attainment and affect their fertility choices. Second, specific English-learning programs at school for young immigrants that arrived in the UK at age eight or later would be particularly beneficial for them, since having arrived in the UK after the critical period of language acquisition makes it more difficult for them to learn the language. Specific language support classes could have an important impact in their capability to obtain qualifications or pursue higher degree studies. In addition, our results contribute to the public debate on the integration of immigrants, providing some evidence against the mainstream idea that claims that the lack of integration of immigrants into the UK society is merely due to their social or cultural preferences. We have found that there is a constraint that immigrants face to integrate aside from possible cultural preferences: proficiency in English, and that alleviating this constraint (e.g., supporting immigrants to learn English) could be a successful way to help immigrants better integrate into the UK society. 


\section{Appendix}

Table A1: Immigrants by Country of Birth

\begin{tabular}{|c|c|c|c|c|c|}
\hline \multicolumn{3}{|l|}{ A. English-speaking countries } & \multicolumn{3}{|l|}{ B. Non-English-speaking countries } \\
\hline Country & $\mathrm{N}$ & Percent & Country & $\mathrm{N}$ & Percent \\
\hline Kenya & 789 & 14.3 & Germany & 1160 & 23.1 \\
\hline Ireland & 656 & 11.9 & Somalia & 463 & 9.2 \\
\hline Jamaica & 545 & 9.9 & Cyprus & 336 & 6.7 \\
\hline South Africa & 377 & 6.8 & Turkey & 286 & 5.7 \\
\hline Uganda & 348 & 6.3 & Italy & 153 & 3.0 \\
\hline Nigeria & 302 & 5.5 & Vietnam & 143 & 2.8 \\
\hline United States & 298 & 5.4 & Afghanistan & 134 & 2.7 \\
\hline Singapore & 247 & 4.5 & Portugal & 116 & 2.3 \\
\hline Canada & 246 & 4.4 & Iraq & 113 & 2.2 \\
\hline Australia & 241 & 4.4 & Malaysia & 112 & 2.2 \\
\hline Zimbabwe & 175 & 3.2 & France & 110 & 2.2 \\
\hline Ghana & 153 & 2.8 & Iran & 109 & 2.2 \\
\hline Tanzania & 152 & 2.7 & Yemen & 103 & 2.0 \\
\hline Malta & 151 & 2.7 & China & 79 & 1.6 \\
\hline Zambia & 118 & 2.1 & Kosovo & 75 & 1.5 \\
\hline Guyana & 84 & 1.5 & Poland & 74 & 1.5 \\
\hline New Zealand & 76 & 1.4 & Malawi & 68 & 1.4 \\
\hline Gibraltar & 56 & 1.0 & Netherlands & 64 & 1.3 \\
\hline Sierra Leone & 53 & 1.0 & Saudi Arabia & 63 & 1.3 \\
\hline Trinidad and Tobago & 53 & 1.0 & Spain & 59 & 1.2 \\
\hline Mauritius & 42 & 0.8 & Egypt & 50 & 1.0 \\
\hline St Kitts and Nevis & 31 & 0.6 & Belgium & 43 & 0.9 \\
\hline Isle Of Man & 29 & 0.5 & Sudan (South Sudan and Sudan) & 43 & 0.9 \\
\hline St Lucia & 29 & 0.5 & Libya & 42 & 0.8 \\
\hline Barbados & 29 & 0.5 & Lebanon & 40 & 0.8 \\
\hline St Vincent and The Grenadines & 26 & 0.5 & Russia & 37 & 0.7 \\
\hline Montserrat & 24 & 0.4 & Sweden & 34 & 0.7 \\
\hline Grenada & 24 & 0.4 & Thailand & 33 & 0.7 \\
\hline Jersey & 24 & 0.4 & Angola & 32 & 0.6 \\
\hline Total top 30 & 5394 & 97.5 & Total top 30 & 4206 & 83.6 \\
\hline
\end{tabular}

Notes: $\mathrm{N}$ refers to the number of individuals by country of birth for the top 30 countries present in our sample. Panels A and B present the control group (i.e., English-speaking countries) and the treatment group (i.e., non-Englishspeaking countries), respectively.

Source: Authors' calculations based on the ONS England and Wales Longitudinal Study dataset. 


\section{References}

Adsera, A., \& Ferrer, A. (2014). Factors influencing the fertility choices of child immigrants in canada. Population Studies, 68(1), 65-79.

Akbulut-Yuksel, M., Bleakley, H., \& Chin, A. (2011). The effects of English proficiency among childhood immigrants: Are hispanics different? In D. L. Leal, \& S. J. Trejo (Eds.) Latinos and the Economy, Immigrants and Minorities, Politics and Policy, (pp. 255-283). Springer New York.

Angrist, J. D., \& Pischke, J.-S. (2009). Mostly harmless econometrics: An empiricist's companion. Princeton: Princeton University Press.

Barro, R., \& Lee, J.-W. (2013). A new data set of educational attainment in the world 1950-2010. Journal of Development Economics, 104(C), 184-198.

Bauer, A. M., Chen, C.-N., \& Alegria, M. (2012). Prevalence of physical symptoms and their association with raceethnicity and acculturation in the united states. General Hospital Psychiatry, 34(4), $323-331$.

Black, S. E., Devereux, P. J., \& Salvanes, K. G. (2008). Staying in the classroom and out of the maternity ward? The effect of compulsory schooling laws on teenage births. The Economic Journal, 118(530), 1025-1054.

Bleakley, H., \& Chin, A. (2004). Language skills and earnings: Evidence from childhood immigrants. The Review of Economics and Statistics, 86(2), 481-496.

Bleakley, H., \& Chin, A. (2010). Age at arrival, English proficiency, and social assimilation among US immigrants. American Economic Journal: Applied Economics, 2(1), 165-92.

Böhlmark, A. (2008). Age at immigration and school performance: A siblings analysis using Swedish register data. Labour Economics, 15(6), 1366 - 1387.

Chiswick, B. R., \& Miller, P. W. (2014). International migration and the economics of language. In B. R. Chiswick, \& P. W. Miller (Eds.) Handbook on the Economics of International Migration. Elsevier.

Clarke, A., \& Isphording, I. E. (2015). Language barriers and immigrant health production. IZA discussion paper 8846, Institute for the Study of Labour. 
Cohen Goldner, S., \& Epstein, G. S. (2014). Age at immigration and high school dropouts. IZA Journal of Migration, 3(1).

Corak, M. (2011). Age at immigration and the education outcomes of children. IZA Discussion Papers 6072, Institute for the Study of Labor (IZA).

Cortes, K. E. (2006). The effects of age at arrival and enclave schools on the academic performance of immigrant children. Economics of Education Review, 25(2), 121-132.

Dustmann, C., \& van Soest, A. (2001). Language fluency and earnings: Estimation with misclassified language indicators. The Review of Economics and Statistics, 83(4), 663-674.

Freedom House (1973). Freedom in the world. Accessed on 15 July 2015. URL https://freedomhouse.org/report-types/freedom-world

Glick, J., \& White, M. (2003). Academic trajectories of immigrant youths: Analysis within and across cohorts. Demography, 40(4), 759-783.

Gorwaney, N., Van Arsdol, M. D., Heer, D. M., \& Schuerman, L. A. (1991). Migration from Latin American countries to the United States: The economic, social and reproductive lives of hispanic female immigrants, 1980. International Migration, 29(4), 573-599.

Guven, C., \& Islam, A. (2015). Age at Migration, Language Proficiency, and Socioeconomic Outcomes: Evidence From Australia. Demography, 52(2), 513-542.

Janssen, S. (2010). The World Almanac and Book of Facts 2011. New York: Infobase Learning.

Jayaweera, H. (2014). Health of migrants in the UK: What do we know? The migration observatory, University of Oxford. Accessed on 11 December 2014.

URL http://migrationobservatory.ox.ac.uk/briefings/ health-migrants-uk-what-do-we-know

Kimbro, R. T., Gorman, B. K., \& Schachter, A. (2012). Acculturation and self-rated health among Latino and Asian immigrants to the United States. Social Problems, 59(3), pp. 341363.

Lee, S., ONeill, A., Ihara, E., \& Chae, D. (2013). Change in self-reported health status among immigrants in the United States: Associations with measures of acculturation. PLOS ONE, 8(10), 76494.

Lenneberg, E. H. (1967). Biological foundations of language. New York: Wiley. 
Lichter, D. T., Johnson, K. M., Turner, R. N., \& Churilla, A. (2012). Hispanic assimilation and fertility in new U.S. destinations. International Migration Review, 46(4), 767-791.

Miranda, P. Y., Gonzalez, H. M., \& Tarraf, W. (2011). Pathways between acculturation and health: Does the measure matter? Hispanic Journal of Behavioral Sciences, 33(4), 524-539.

Ng, E., Pottie, K., Spitzer, D., Mohammed, A., \& Glazier, R. (2008). Language proficiency, gender and self-reported health: An analysis of the first two waves of the longitudinal survey of immigrants to Canada. Canadian Journal of Public Health, 99(6), 505-510.

OECD (2012). Settling in: OECD indicators of immigrant integration 2012. Accessed on 11 December 2014.

URL http://dx.doi.org/10.1787/9789264171534-en

Swicegood, G., Bean, F. D., Stephen, E. H., \& Opitz, W. (1988). Language usage and fertility in the mexican-origin population of the United States. Demography, 25(1), pp. 17-33. 